\title{
The use of WhatsApp in collaborative learning to improve English teaching and learning process
}

La Hanisi, Ajid

Ahmad Dahlan University, Indonesia (ajidternate@yahoo.com)

Risdiany, Reni

Ahmad Dahlan University, Indonesia (renyabadi@gmail.com)

Dwi Utami, Yunita

Ahmad Dahlan University, Indonesia (yunitadwiutami@gmail.com)

Sulisworo, Dwi $\$

Ahmad Dahlan University, Indonesia (sulisworo@gmail.com)

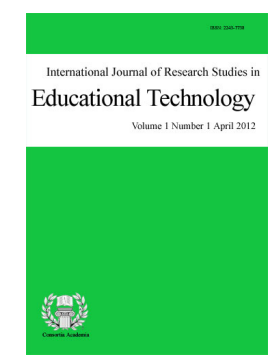

ISSN: $2243-7738$ Online ISSN: 2243-7746

OPEN ACCESS

\section{Abstract}

Students are inseparable by their mobile phone. They do many things on the phone such as texting, uploading and downloading pictures and videos, reading the flash news, or just browsing. However, the rapid growth of mobile phone technology sometimes distracts them from their learn activities in the class. They don't put their focus much on the lesson because of the attention to their mobile phone. Thus makes teacher should be creative enough to find an alternative way to anticipate this phenomenon. Collaborative learning using collaborative tools tend to be applied due to its activities combine collaboration of students and the use of mobile phone application. This article attempts to study the use of WhatsApp in English language classroom to optimize the function of the mobile phone for students' learning process. Supported activities in four language skills are presented to give teacher choice of English teaching. It can be said that the integration of WhatsApp into their education will be easy, fun, and useful. Students get positive feelings and intentions regarding the possible use of WhatsApp in their formal learning.

Keywords: collaborative learning; collaborative tool; English language teaching; WhatsApp; social media 


\section{The use of WhatsApp in collaborative learning to improve English teaching and learning process}

\section{Introduction}

Today, technology has become a part of human life. They cannot be separated by the technology because almost all aspects of life are supported by technological advances. One issue is communication. Humans can communicate easily by mobile phones. Besides the ability to access the internet, mobile phones allow humans to get all the information they want. Students have the same condition as other people. They make their mobile phones an inseparable part of themselves. Almost every time they use it for various things, access social media, play online games, upload and download photos and videos or just read flash news about everyday events around the world.

These rapid technological developments, on the other hand, have a disastrous impact on students. They become less focused on the lessons because they play more with their mobile phone during the experience, and in worse conditions, students decrease their ability to interact and work with friends and teachers directly (Sulisworo, Yunita, \& Komalasari, 2017). Collaborative learning can be used by combining collaborative tools to prevent the worse things. The mobile phone is used as a collaborative tool for students with the support of collaborative learning strategy (Sulisworo, Rahayu, \& Akhsan, 2016). Students will be directed to work with their friends. Also they can still communicate via the application on their mobile phone.

One application that can be used is WhatsApp. In the features provided, students and teachers can interact with each other online. Discussion groups allow them to communicate, have the discussion, and send pictures, recordings and more. All activities can be arranged by teachers so that students can improve their skills in English during the classroom activities.

This article attempts to study the use of WhatsApp in English language classroom to optimize the function of mobile phone for students' learning process. Also, it aims to improve students' cooperative skill in the process of completing their tasks and overcoming their problems.

\section{Literature Review}

\subsection{Concept of Collaborative Learning and Collaborative Tools}

Collaborative learning is an instruction given to the students various ability to work together in the group to reach goals. The students are responsible for one another's learning as well as their own (Khosa \& Volet, 2014). Thus, the success of one student helps other students to be successful. According to Alavi, Wheeler, and Valacich (1995), collaborative learning is an activity which involves the group of students collaborating to accomplish the problem-solving task given as learning activities requirement. The collaboration, as mentioned by Patel, Pettit, and Wilson (2012), involves two or more participants to interact each other, at the particular period, working together to achieve the same goal.

The activities in collaborative learning do not only work together but also require team-work with defined roles to reach group success (Coll, Rochera, \& de Gispert, 2014). Lizzio and Wilson (2006) indicate the factors which contribute the effectiveness of collaboration; those are team-building activities, the frequency of meetings, and the value that individuals place on the process of learning, or goal orientation. The primary purpose of these events is developing students' ability in the process to be autonomous learners (Knight \& Yorke, 2003).

Collaborative activities have the potential to boost more reticent language learners' confidence to participate 
in classroom activities (Ur, 1996) and to help them maintain their self-esteem, overcome their shyness and lack of self-confidence, and learn interpersonal relationships. Collaboration activities in the group can be done without physical meetings of its member by using collaborative tools. Collaborative tools are usually web-based, it can be accessed by the user easily. Web-based tools can support group collaboration activities with no requirement to pay at the high price, it just needs to use internet access, and there is no requirement to have other additional hardware (Yücel \& Usluel, 2016). Becker and Cline (2005) gives some tools considered as collaborative ones such as e-mail, audio conferencing, collaborative presentation software, conference room video-conferencing, desktop video conferencing, discussion database, document management software, electronic white boarding, group authoring, GDSS, group scheduling and calendaring, knowledge management systems, one-way bulletin boards (BBS), personal communication tools like laptop, mobile phone, pagers, and so on.

\subsection{The Use of WhatsApp as Collaborative Tool}

WhatsApp Messenger is a smartphone- and web-based instant message application that allows users to exchange information using a variety of media including text, image, video, and audio messages (Church \& de Oliveira, 2013). It is a free, easy to use, fast, convenient, the personal mode of communication. Also, it is not only text messaging, but users can also send each other image, video, and audio messages. WhatsApp allows its users to use their Internet connection to send messages to each other. WhatsApp is a chat program for mobile phones. Smartphones are acceleratively popular, and WhatsApp is available on almost every Smartphone.

As a free messenger application, it works across multiple platforms like iPhone and Android phones, and this app is being widely used among undergraduate students to send multimedia messages like photos, videos, audios along with simple text messages (Chan \& Holosko, 2017). Since internet facility is required for using WhatsApp, lots of information can also be accessed in real time, and sharing that information through technology is both instantaneous and convenient. According to Aburezeq (2012), WhatsApp messenger has the following collaborative features:

$>$ Multimedia: It allows the user to exchange videos, text messages, images, and voice notes.

$>\quad$ Group Chat: It supports the interaction of up to 50 group members.

$>$ Unlimited Messaging: The number of messages you can share on WhatsApp is unlimited. The application uses 3G/EDGE internet data plan or Wi-Fi to ensure continuous data transmission across platforms.

$>$ Cross-Platform Engagements: Interactions with different devices (personal digital assistants, Smartphones, Galaxy tablets) can message one another through various media (text messages, pictures, videos, voice notes).

$>$ Offline Messaging: Messages are saved automatically when the device is off or outside the coverage area.

$>\quad$ No Charges involved: there are no charges involved in using WhatsApp as it uses same internet data plan which is used for email or web browsing.

$>\quad$ Pins and Users Name: WhatsApp, the user, need not remember passwords or username as it works via phone numbers and integrates with users address books.

There is also an emerging evidence that these Apps have a significant potential to support the learning process and has substantial implications on pedagogies, allowing direct access to lots of online resources, more focus on student's creativity, autonomy, and responsibility on one's own learning (Ifenthaler \& Schweinbenz, 2016). Language learners have a more opportunity to listen and speak that language in their classroom with their friends and teacher, while they are not, they can extend their communication by connecting the application in their phones freely. It is such a considerable way to serve learners to communicative users undertaking. Learners are beneficially by the expanding exercise and experience through free knowledge. 


\section{Activities in EFL Classroom}

\subsection{Listening}

Technology offers a number of electronic tools in and outside the classroom that can help in the teaching and learning process (Chun, Kern, \& Smith, 2016). In developing listening skill by the use of WhatsApp application, the teacher can do the following actions:

$>$ The teacher sends an audio recording and asks the students to listen to it, and ask them to take a note while looking.

$>$ The teacher shares an English conversation video and asks the students to watch and listen to the video. After that, he asks them to give the comment or discuss the question based on the video.

$>\quad$ The teacher gives pre-listening activity related to the story which is going to play. The questions focus on the structure of the story, characters, such as:

- Who is the main character of the story?

- Where/when does the story take place?

- What do you think of the ending of the story will be? Etc.

\subsection{Speaking}

WhatsApp Application is available with its features for learning speaking. Jafari \& Chalak (2016) in their research towards 60 students including 30 male and 30 female students found that the participants, both male and female, who had benefited from mobile-assisted learning, had a significantly better performance on a speaking post-test than the participants in the control group.

In speaking class, students can discuss the chat room on the WhatsApp group. The students can find the topic of a debate themselves or the teacher can also give a suitable theme for learning activities. The teacher continues asking them to record the voice, before sending to WhatsApp group. The operation can be conducted such as:

The students register their oral reading of a story and then throw them in the team.

$>$ For improving students' speaking performance, the teacher tells them when they have to record their speaking; they can re-record it and repeat as they want until they are satisfied that their recording is the best they can produce.

$>$ For higher classes, the students can retell the story and record it.

\subsection{Reading}

In improving reading skills of students, the teacher sends a simple reading text, such as short story, in the WhatsApp group. The short story is beneficial to give students exercises for improving their vocabulary and reading. The activities which can be conducted to help students in acquiring more vocabulary are:

$>\quad$ Ask the students to read the story and understand it.

$>$ Ask the students to find the definition of some words.

$>$ Choose the word/phrase listed to fill the blanks of the text. In this activity, students then practice using the words they know. Intermediate and advanced students also profit from the literary book. What they read gives them the opportunity to come up with their insights and help them speak the language in the more imaginative way. Students will be more creative since they are faced with their point of view.

Research has been conducted by Muthaiyan and Kanchana (2016) related to students' motivation in reading 
through WhatsApp. It has been done towards the first year students of SVS College of Engineering in Coimbatore. The result shows that the students have more interest to use reading message on social media (WhatsApp). Another comparative study conducted by Ta'amneh (2017), is the comparison between traditional instruction and the use of WhatsApp messenger towards 40 students in Badr Community College at Taibah University. The students are divided into two groups. The control group consists of 21 students taught traditionally while the experimental team consists of 19 students prepared by using the combination of WhatsApp and traditional learning. The finding indicates that the trial group using combination method (WhatsApp and regular) can learn more efficiently than the control group which learns only in the traditional way (face to face).

\subsection{Writing}

Helping students to develop their writing skill, the teacher can create a variety of writing activities in WhatsApp group. Fattah (2015) in his research finds that WhatsApp technology can enhance students' active participation in the EFL classroom. It can provide students with an opportunity for practicing the language for free, a more personal and comprehensive relationship between students and teachers, a chance for students not to be more sociable only, but also to learn better, and an opportunity for students to synchronize their opinions with others'.

In teaching writing via WhatsApp, the teacher can ask students to write comments on the topic of discussion or more complex writing activities. Students can also be asked to write any responses raised by the teacher in the group discussion of WhatsApp which can help them to improve their writing skill. The teacher can send the picture of a place in WhatsApp and ask the students to answer "Where is it?" or ask them to write and describe the situation.

Richard (2015) divides writing activity into three steps; pre-writing activity, writing activity, and post writing activity. In the pre-writing activity, the teacher shares a picture/a video about flood happened in Jakarta, for example. Then invites the students to comment and express their feeling about the disaster. The primary activity is done by group drafting, then completing the template and working like a snowball. One student drafts and shares, the other students complete and share again. And then, in Post-Writing Activity, the teacher gives feedback to the students' writing by making use of recording (voice), so the students can listen to the teacher's voice in providing comment about their writing (Susanti \& Tarmuji, 2016).

\section{Conclusion}

This study has highlighted the use of WhatsApp for educational purposes. Our paper shows that WhatsApp is beneficial to students' knowledge of the language. The cheapness and potential of this application bring us to the easy way to communicate. Some people ask questions, ask one another for help, and the others share their solutions. The learning progress is furthered by the teacher's guidance, the creation of a supportive atmosphere, the creation of a learning community, and the sharing of knowledge and inspiring dialogue. The teacher invites students to have the group or private chats with him and encourages the students to help each other. The teacher should praise students, initiate discussion, and use WhatsApp to confirm whether students do understand the topics or not. The teacher can also use WhatsApp to get to know the students better. As Bouhnik and Deshen (2014), the advantages to the use of WhatsApp in teaching is the broad availability of the teacher to the students, the opportunity for students to help one another, and the opportunity for more in-depth acquaintance with the students on the educational and personal levels. However, students as the participants have positive perceptions of the formal use of WhatsApp to support their learning. It can be said that the integration of WhatsApp into their education will be easy, fun, and useful. Students get positive feelings and intentions regarding the possible use of WhatsApp in their formal learning. 


\section{References}

Aburezeq, I. M., \& Ishtaiwa, F. F. (2013). The impact of WhatsApp on interaction in an Arabic language teaching course. International Journal of Arts \& Sciences, 6(3), 165-180.

Alavi, M., Wheeler, B. C., \& Valacich, J. S. (1995). Using IT to reengineer business education: An exploratory investigation of collaborative telelearning. MIS quarterly, 19(3), 293-312. https://doi.org/10.2307/249597

Becker, J. D., \& Cline, M. (2005). Effectiveness of collaborative tool usage for virtual team activities. AMCIS 2005 Proceedings (Vol. 3, pp. 1397-1401). Omaha: Association for Information System.

Bouhnik, D., \& Deshen, M. (2014). WhatsApp goes to school: Mobile instant messaging between teachers and students. Journal of Information Technology Education: Research, 13, 217-231. https://doi.org/10.28945/2051

Chan, C., \& Holosko, M. J. (2017). The utilization of social media for youth outreach engagement: A case study. Qualitative Social Work, 16(5), 680-697. https://doi.org/10.1177/1473325016638917

Chun, D., Kern, R., \& Smith, B. (2016). Technology in language use, language teaching, and language learning. The Modern Language Journal, 100(S1), 64-80. https://doi.org/10.1111/modl.12302

Church, K., \& de Oliveira, R. (2013). What's up with whatsapp?: comparing mobile instant messaging behaviors with traditional SMS. In Proceedings of the 15th international conference on Human-computer interaction with mobile devices and services (pp. 352-361). New York: ACM. https://doi.org/10.1145/2493190.2493225

Coll, C., Rochera, M. J., \& de Gispert, I. (2014). Supporting online collaborative learning in small groups: Teacher feedback on learning content, academic task and social participation. Computers \& Education, 75, 53-64. https://doi.org/10.1016/j.compedu.2014.01.015

Fattah, S. F. E. S. A. (2015). The effectiveness of using WhatsApp messenger as one of mobile learning techniques to develop students' writing skills. Journal of Education and Practice, 6(32), 115-127.

Ifenthaler, D., \& Schweinbenz, V. (2016). Students' acceptance of tablet pcs in the classroom. Journal of Research on Technology in Education, 48(4), 306-321. https://doi.org/10.1080/15391523.2016.1215172

Jafari, S., \& Chalak, A. (2016). The role of WhatsApp in teaching vocabulary to Iranian EFL learners at junior high school. English Language Teaching, 9(8), 85. https://doi.org/10.5539/elt.v9n8p85

Khosa, D. K., \& Volet, S. E. (2014). Productive group engagement in cognitive activity and metacognitive regulation during collaborative learning: can it explain differences in students' conceptual understanding? Metacognition and Learning, 9(3), 287-307. https://doi.org/10.1007/s11409-014-9117-z

Knight, P., \& Yorke, M. (2003). Assessment, learning and employability. McGraw-Hill Education.

Lizzio, A., \& Wilson, K. (2006). Enhancing the effectiveness of self-managed learning groups: Understanding students' choices and concerns. Studies in Higher Education, 31(6), 689-703. https://doi.org/10.1080/03075070601004309

Muthaiyan, M., \& Kanchana, K. (2016). A study on developing reading skills of engineering students through WhatsApp as motivational. International Journal of English Research, 2(3), 1-04.

Patel, H., Pettit, M., \& Wilson, J. R. (2012). Factors of collaborative working: A framework for a collaboration model. Applied Ergonomics, 43(1), 1-26. https://doi.org/10.1016/j.apergo.2011.04.009

Richard, J. C. (2015). Key issues in language teaching. UK: Cambridge University Press.

Sulisworo, D., Rahayu, T., \& Akhsan, R. N. (2016). The students' academic writing skill after implementing blended learning using Facebook. Information Technologies and Learning Tools, 56(6), 176-191.

Sulisworo, D., Yunita, L., \& Komalasari, A. (2017). Which mobile learning is more suitable on physics learning in Indonesian high school? International Journal of Recent Contributions from Engineering, Science \& IT, 5(1), 97-104.

Susanti, A., \& Tarmuji, A. (2016). Techniques of optimizing Whatsapp as an instructional tool for teaching EFL writing in Indonesian senior high schools. International Journal on Studies in English Language and Literature , , 4(10), 26-31.

Ta'amneh, M. A. A. A. (2017). The effect of using Whatsapp messenger in learning English language among 
The use of WhatsApp in collaborative learning to improve English teaching and learning process

university students. International Research in Education, 5(1), 143-151.

https://doi.org/10.5296/ire.v5i1.10801

Ur, P. (1996). A course in language teaching: Practice and theory. Cambridge: Cambridge University Press.

Yücel, Ü. A., \& Usluel, Y. K. (2016). Knowledge building and the quantity, content and quality of the interaction and participation of students in an online collaborative learning environment. Computers \& Education, 97, 31-48. https://doi.org/10.1016/j.compedu.2016.02.015 
La Hanisi, A., Risdiany, R., Dwi Utami, Y., \& Sulisworo, D. 